\title{
Virtual reality technology and physical distancing: A review on limiting human interaction in tourism
}

\author{
Ozan Atsiz
}

ABSTRACT

Keywords:

Pandemics,

COVID-19,

Virtual reality technology

\author{
Article History: \\ Submitted: 01.09.2020 \\ Accepted: 27.01.2021
}

\begin{abstract}
While the COVID-19 pandemic has been influencing almost all industries since the end of the first quarter of 2020, its impact appears to be more prominent in the tourism industry. Extant research emphasizes that this effect will continue and individuals abstain from travel to avoid being among other people. To maintain physical distancing and recover the tourism industry, virtual reality technology has been adopted to give travelers the opportunity to visit certain destinations and try products or services, which can be a useful tool to consider physical distancing in tourism. Further to this, this research reviews that tourist destinations and tourism businesses such as accommodation, food and beverage, and museums can utilize virtual reality technology to prevent the spread of COVID-19. Furthermore, COVID-19 can be seen as a chance for both the industry and the destination to market their products and services. Therefore, this technology will be extremely helpful for the revival of tourism post-COVID-19.
\end{abstract}

\section{Introduction}

The novel coronavirus (hereafter COVID-19), first known as "2019 novel coronavirus" and reported in Wuhan, China on December 31, 2019, has already spread across the world from person-to-person transmission (World Health Organization, 2020). Although there are a limited number of treatment methods in terms of medical capabilities, the best ways to keep the virus under control are nonpharmaceutical interventions; i.e. the actions taken by people without medication to slow the spread of the pandemic (Gössling, Scott, \& Hall, 2020). The vast majority of countries have implemented numerous nonpharmaceutical interventions, including quarantine, lockdowns, border control, social and physical distancing, and self-isolation practices prohibiting human gatherings more than a few people (Anderson, Heesterbeek, Klinkenberg, \& Hollingsworth, 2020; Wen, Wang, Kozak, Liu, \& Hou, 2020). These precautions have impacted a wide range of sectors worldwide. Tourism (including transport and tour operators, accommodation and food services, business meetings and events, travel technology companies, and tour guides) is among the most impacted (OECD, 2020; World Tourism Organization, 2020). Furthermore, the World
Tourism Organization (2020b) issued a report about restarting tourism while stopping the spread of this disease by reducing or managing a destination's capacity to implement appropriate social or physical distancing measures to reduce the number of people gathering.

As a result of the outbreak of COVID-19, perceived health, social and psychological risk have occurred from the side of the tourism demand and massive fiscal deficits, job losses, business liquidation and human capital depletion were revealed from the supply-side of the tourism industry (Matiza, 2020, p.5). Today, promising improvements on coronavirus treatments were revealed and some COVID-19 vaccines are developing in different countries. Despite this, a Phase III trial in clinical research has not yet been completely passed by a COVID-19 vaccine candidate. Therefore, this illness and fear of coming together with other people will last for a while. Furthermore, research by Kock, Nørfelt, Josiassen, Assaf, and Tsionas (2020) emphasized that fear of COVID-19 infectability impacted the participating in crowded places and groups.

A report published by the World Tourism Organization (2020a) investigating the influence of 
COVID-19 on international tourism noted that the outbreak has created some opportunities for destinations and service providers in terms of innovation and digitalization. Some studies thus far have offered new technologies and innovations for the tourism businesses such as service robots (Seyitoğlu \& Ivanov, 2020), autonomous vehicles, drones (Zeng, Chen, \& Lew, 2020), and Virtual Reality (VR) or Extended Reality (Kwok \& Koh, 2020) that may help decrease human-to-human interaction and the potential spread of the disease. As one of the most crucial technological tools, VR can be beneficial to relieve the anxieties and concerns of tourists (Guttentag, 2010). This technology may further contribute to promote destination attractions, market tourism products, or services and make travel easier for tourists to experience destinations (Tussyadiah, Wang, \& Jia, 2017). VR provides tourists the ability to experience certain products or services without human contact. Therefore, under such hazardous conditions, destinations, and businesses are encouraged to pay attention to this technology (Loureiro, Guerreiro, \& Ali, 2020). A study by Menegaki (2020) emphasized that VR technology can be adopted by tourist areas like theme parks or archaeological sites, museums, and other crowded places at a destination. For example, tourists can participate in a selection of games. These technologies don't enhance the experiences of tourists but also provide an understanding of tourism sustainability (Cranmer, tom Dieck, \& Fountoulaki, 2020). However, in such periods that people don't want to travel to crowded places and desire to experience things that are needed less human interaction, VR technology can provide all types of experiences without physically participating in the activity or going to a destination (Buhalis \& Motloka, 2013). In their study by Mohanty, Hassan, and Ekis (2020), they concluded that physical distancing and less mobility in the tourism industry will be pursued even after this outbreak. Thus, the demand for technologies based on VR is going to increase. These will provide safety for them and distinctive, accessible, customized, context-specific, profound, and unforgettable experiences.

Although research emphasizing the role of VR or Information and communications technology (ICT) in various destinations or types of tourism during COVID-19 are in the early stages, the upsurge using these technologies in the post this disaster is expected to increase in the future (Mora, 2020). Furthermore, studies on utilizing these technologies which are required less human interactions are limited and are receiving attention from scholars in recent years (Mohanty et al., 2020; Seyitoğlu, \& Ivanov, 2020). This paper attempts to review that a VR-based tourism experience can provide an alternative technological tool for traveling while physically distancing in such a disaster. Furthermore, travel companies, destination managers, and tourism businesses who adopt this technology for their products and services may extra revenue and survive longer in the industry.

\section{COVID-19 and Tourism}

COVID-19 impacted a wide range of countries and many sectors that can take a long for an extended period of time. Currently, cases of coronavirus reached over 65 million worldwide, 1,5 million deaths are reported and it affected 218 countries and territories (Worldometers, 2020; URL: https://www.worldometers.info/coronavirus/).

Moreover, many sectors including tourism, hospitality, aviation, textile, agriculture, construction, gems/jewelry, and start-ups (Debata, Patnaik, \& Mishra, 2020, p.3) are impacted due to this crisis. However, the tourism and hospitality industry is one of the severest influenced in all destinations (Nicola et al., 2020).

In the tourism industry, some researchers mention about the crisis that occurred as a result of COVID19 that 'things will never be the way they used to be' (Zenker \& Kock, 2020). Despite this understanding, many destinations tried to occur the negative effects of this disaster on their tourism economy. Then, they attempted to improve destination facilities and enhance the visitor experience in the destination based on these situational reports. Furthermore, the World Tourism Organization and the majority of tourism scholars produced some recovery strategies for tourism destinations by determining the main impacts of COVID-19.

During the pandemic time, all countries closed their borders and did not accept visitors in order to stop the spread of it. This has led to very low or no mobility for the tourism industry (Uğur \& Akbıyık, 2020). This caused so a sharp decrease in tourist arrivals that many tourism businesses and workers or tourism-related activities are impacted due to this. According to a report by the World Tourism Organization (2020c), unprecedented negative economic impacts will have occurred at the end of 2020. For example, export proceeds (export from tourism - international visitors' spending) from the tourism industry is expected to decline by 910 billion to $\$ 1.2$ trillion in 2020 and 
global GDP is anticipated to fall by $1.5 \%$ to $2.8 \%$. Tourism is one of the leading industries that depend on human resources and supports one in 10 jobs worldwide. Moreover, the livelihoods of many people are created from tourism as well in many economies. Also, in this report, it is stated that 100 million direct tourism jobs are at risk. Especially, tourism-dependent destinations will be the worst affected ones in the world.

It has been revealed that fear, which occurs during pandemic periods and is one of the basic emotional reactions, is largely the cause of the changes in individuals' behavior (Witte \& Allen, 2000). Travel behavior of tourists was also influenced by the COVID-19 due to that this crisis turned into a main media event and a global disaster (Neuburger \& Egger, 2020). These risk perceptions cause to alter individuals' travel plans and stay at home rather than traveling to a specific destination (Pennington-Gray, Schroeder, \& Kaplanidou, 2011). Additionally, tourists' future behavioral intentions to certain destinations will change and travel to less human interaction areas, such as rural destinations (Aydın \& Doğan, 2020). Therefore, it is suggested that investments in such places will attract tourists to visit the destination and promote to other potential visitors. This will provide a sustainable strategy for destinations, too (Vaishar \& Štastná, 2020). Moreover, this disaster is viewed as a chance for destinations to improve and product their touristic products via a wide range of technological travel tools such as Extended Reality or Virtual Reality (Kwok \& Koh, 2020). Especially, tourism destinations and businesses can use these travel tools to reduce worries and concerns of tourists desiring to visit their destination (Guttenberg, 2010). These travel means are regarded as one of the major digital technologies that would accelerate and recover the tourism industry and tourism products offered by businesses. These tools are not only considered to encourage people to travel to any destination but also will be extremely helpful for the millions of people working in the tourism industry (Phocuswire, 2020).

\section{Virtual Reality (VR) Technology and Its Benefits During the COVID-19 Pandemic}

VR is described as "the use of a computergenerated 3D environment - called a 'virtual environment' (VE) - that one can navigate and possibly interact with, resulting in real-time simulation of one or more of the user's five senses" (Guttentag, 2010, p.638). It is one of the most remarkable technological tools to experience a service or product and "travel" to a destination. VR technologies enable tourists to travel and gain information about a destination without considering borders or the distance of any destination. It also changes the travel patterns and experiences of tourists at the destination (Kim \& Hall, 2019). According to the World Economic Forum (2017), estimated consumer spending on VR is anticipated to upsurge to $\$ 200$ billion by 2027 . Another forecast of VR market size mentioned that it would be $\$ 209.2$ billion in 2022 (Statistica, 2020). The longevity of VR technology will generally increase its market share and undoubtedly develop its capacity to arouse our five senses in the future (Guttentag, 2010).

VR technology is proposed for some natural destinations that are sensitive and fragile (Karadimitriou, 2020). For example, some areas are in danger because of the volume of tourists such as the Russian and Canadian Arctic, Greenland, Alaska, and the Himalayas (Huddart \& Stott, 2020). These destinations can use VR tools to preserve and deliver their resources to future generations. According to Karadimitriou (2020), tourists have a chance to experience destination attractions by considering the environmental equilibrium. During the pandemic, some researchers emphasized that VR technology is extremely helpful for patients' treatment, medical marketing, disease awareness, and pedagogical methods (Singh et al., 2020). They highlighted that VR is the best way to decrease face-to-face interaction between individuals. Javaid et al. (2020) discussed how VR enables people to come together without the need to travel and gives them the opportunity to help stop COVID-19. It also has benefits such as reduced trip costs for individuals, improved efficiency and performance of some businesses, and reduced effects of absenteeism or negative environmental impacts among destinations. Furthermore, the attractions shared via VR may impact the decision-making of tourists and help promote the destination itself, thus increasing its popularity (Morosan \& Bowen, 2018).

Pandemic has been regarded as one of the pivotal threats to businesses and it is one of the key hazards that all businesses should take pandemic preparedness (Smith, Hansen, Spanbauer, \& Shell, 2007). In order to over this issue, it is highlighted to adopt their products and services into online operations and virtual techs are good tools for some customer experience in terms of considering physical distancing (Kim, 2020). During the 
COVID-19 pandemic, many customers have changed their travel patterns that do not include transportation and accommodation due to corona phobia (Ting, Ling, \& Cheah, 2020). Therefore, it is predicted that virtual travels that allow tourists not to interact with anybody in the destination will increase in the post-COVID-19 era. Travel companies will offer their services via virtual marketing before the trial of experience and destination will promote their attractions via VR. For example, Ocean Rift enables tourists to experience the underwater ecosystem and Google Expeditions provide users to travel to any point on Earth (Guha, 2020). However, tourism is defined as 'it comprises the activities of persons traveling to and staying in places outside their usual environment" that are supported by the United Nations and the World Tourism Organization (Wall \& Mathieson, 2006). When considered this definition, travelers should visit the destination to use VR and this will enable less interaction at crowded tourist sites. Guttentag (2010) implied that "an Australian resident would be considered a tourist when exploring a VR Petra application situated in a British museum, but if the same Australian explored the same VR application at home then he or she would not be considered a tourist (p.647)." Thus, the usage of this tech depends on tourist movement to the destination at least.

\section{The role of VR as a tool for physical distancing in Tourism}

Tourism is the worst impacted of all sectors due to COVID-19 and its effect is expected to remain for a while because people will avoid traveling into the crowded tourism areas for not interacting with other tourists and locals (Nicola et al., 2020). Therefore, the World Tourism Organization (2020) offers restart tourism on condition that some serious measures are introduced by governments such as safety and hygiene protocols. Physical distancing is one of the key check procedures in these protocols and it is emphasized the role of technological developments in considering physical distancing in tourism businesses and destinations. In another evaluation paper on tourism recovery, ensuring physical distancing may be possible to implement some technologies including automation 'technologies', 'robots' and 'artificial intelligence' and this measure can reduce social interaction of tourists during this crisis (Assaf \& Scuderi, 2020). In a similar, VR technology can be used for physical distancing as a pillar for serious pandemics or tourism recovery (Guha, 2020).
VR technology was adopted in a wide range of tourism areas during the COVID-19 such as meetings, incentives, conferencing \& exhibitions (MICE), virtual tourism experiences or virtual tours, archaeological sites, etc. The majority of countries affected by COVID-19 introduces significant measures related to tourism and have issued online virtual tours and meetings (OECD, 2020). It is considered the most important marketing tool for tourism products and services in terms of surviving the hospitality and tourism sectors in such a crisis. There are some benefits of VR for tourists, businesses, and destinations (Tussyadiah, Wang, Jung, \& tom Dieck, 2018). For example, travel companies use a VR app called Travel World VR to market travel experiences for potential tourists. Furthermore, this app allows some destinations to promote their attractions via 360-degree videos and cinematic VR tools. In recent years, especially during the COVID-19, some cruise lines, hotels, and destinations utilized this technology to attract their target customers and visitors. World Travel VR app provides hoteliers to market hotel experience interactively and the slogan of this app was determined as 'try' before-you-buy' experience (Little Black Book, 2020). It is predicted that the understanding of 'try before you buy' will become predominant in the future due to the coronavirus and tourism businesses should take transform their products into VR technology by limiting human interaction (Travel Daily News, 2020).

As for travelers, a great number of applications have offered travelers to experience any destination non-interaction with other people. For instance, many museums utilized VR tech to present theircultural attractions to potential visitors. 'Virtual Underwater Cultural Heritage Museums' is one of the most benefited from this tech (UNESCO, 2020). Mars 2030 provides individuals to experience the surface of Mars via driving Mars Rover and Everest VR enables adventure tourists to climb Everest as a recreational activity (Skinner, 2020). The abundance of these apps will be adopted in a wide range of tourism experiences and it will be extremely helpful for tourists to experience numerous places without traveling and human interaction.

Some museums (art, ethnography, and archeological) and archeological sites have utilized virtual technology to present their assets. For instance, Göbeklitepe Archaeological Site located in Sanliurfa (Turkey) present their attractions and 
site itself to the potential visitors in order to attract them in the future, In particular, the site management promoted this virtual technology during the COVID-19 and many people have visited the site through the virtual tour (Go Turkey, 2020; Holonext, 2020). In similar, the British Museum also exhibited their cultural attractions via this technology at the time of COVID-19 (British Museum, 2020). Furthermore, it is stated that there are 2,500 museums that people can visit virtually (Bishara, 2020).

In the accommodation sector, virtual booking processes, virtual hotel tours, interactive hotel rooms, and beacon technology were provided for leisure travelers. With these technologies, travelers can take some information about the hotel and their reservation without human interaction. The size, price, features of the room, exploring the hotel environment and inside of the hotel, every detail of the room, and a map that is showed the hotel and surrounding area are given to them before completing their reservation. Furthermore, hotel customers can use these technologies after arriving at the hotel as well. For example, check-in services, room-dining offers, and some services can be used via this technology by limiting human interaction in the hotel. The hotels used this technology enables users to reach with their mobile phones, too (Kutsenko, 2019; Tourismart, 2017).

In the food and beverage industry, consumers can see the final presentation state and the original size of the products in the menu with smart table applications. For instance, a 'tech restaurant' located in London offers consumers interactive tables until their order came to the table (Özbay, 2020). Advertising and marketing efforts, tours in the restaurant, and menu design apps are used in the restaurants in the virtual reality technologies (A2VR, 2020).

\section{Concluding remarks}

The main purpose of this paper is to review an alternative technological tool (virtual reality) for traveling while considering physical distancing in such a disaster. After all crises, public assessment, or perception toward visiting some destinations depends on using communication and information networks (Beirman, 2003). Also, during the pandemic, the destination image is damaged, and it is crucial to repair the destination image in terms of bringing people to the destination and changing their perception toward the destination (Ahmad, Jamaludin, Zuraimi, \& Valeri, 2020). In order to create some strategies, media channels and technological tools are considered as the key ones that play a determining role in both destination image repairs and managing individuals' perception for intending to visit the destination (Govers, Go, \& Kumar, 2007). Therefore, at this point, VR technologies can become a vital tool for encouraging people to travel toward the destination and destination image and the perceived destination choice risk of individuals can be managed via utilizing it in destination marketing (Yung et al., 2020). Furthermore, when considering the tourists will not travel to any destination or prefer less human interaction places, tourism businesses can adapt their products and services with VR technologies. Destination managers or planners are advised to prepare some VR programs for promoting and repairing their destination.

When considered a recent study attempted to expect the recovery of tourism arrivals and adverse effects of COVID-19 will last quite a while (Polyzos, Samitas, \& Spyridou, 2020), travelers take into consideration not to interact with people and they stay at home or travel to the destination visited by less tourists. So, VR technology is the most preferred to maintain physical distancing between individuals. As a significant part of the travel industry, VR has been utilized in numerous tourism areas before the outbreak and it is profoundly used during the crisis. Moreover, it becomes a requirement for the tourism industry to adopt their product and services into innovative and new technology. By doing so, it helps tourism businesses, travel companies, and destinations to promote and market their products and services. Although tourism requires tourists to experience attractions on-site, VR technology can be a supporting role when travelers experience the destination by enabling to decrease human interaction.

Continuous, reliable, and touchless travel and educational tools will be adopted to VR technology in the hospitality and tourism industry, and this technology isregarded as the major tool for travelers and service providers in terms of the revival of tourism. Furthermore, this less human interaction technology provides them to improve their experience quality, service offerings, and their human ability. The tourism and hospitality industry will use this technology to construct awareness, promote, consolidate their branding, and gain potential customers' trust through concentrated marketing. Thus, even post COVID19 crisis, this technology will be common among 
service providers and it is advised tourism and hospitality service providers are always using it when they conducted their marketing efforts.

MICE (Meetings, incentives, conferencing, and exhibitions) are fundamental elements of tourism destinations. ICT-based areas were used by a wide range of institutions, scholars, businesses, etc. preparing their meetings in the digital platforms (Mohanty et al., 2020). VR-based technologies can be an extremely helpful tool for MICE tourism (Pearlman \& Gates, 2010) by protecting time and money (Gustafson, 2012). This trend has been followed in this crisis and is predicted to last within the next years, too. Therefore, some destinations and organizations related to MICE can adopt this technology to attendees by enabling them a less human interaction area.

As the negative effects of VR in tourism, VR technology improves sensuous features and is predicted that tourists experience will be changed totally (Guttentag (2010) Although this technology will enhance tourism experiences and offers many advantages for tourists, some threats may occur in the future. For example, tourists might not visit a destination and this can harm the nature of tourism because it requires a movement to a particular destination (Cheong, 1995). In addition, VR technology doesn't provide tourists to touch a product, try food, smell nature, and contact a local. Thus, even though the travel behaviors of tourists change, these sensory aspects of the tourist experience will be every time. As a result of VR, tourism revenues of destinations can reduce, and job losses, business liquidation, and human capital depletion can occur. More specifically, this research delivers some certain managerial recommendations from which hospitality and tourism practitioners can benefit, consisting of the following suggestions:

- It is thought that physical distancing among leisure travelers will continue and they will be stimulated with some drivers to visit a destination. In order to encourage them to travel to a destination, planners should promote their natural and cultural attractions via VR. These efforts should be heavily utilized.

- VR is used in different sectors such as online shopping, concerts, sports, and museum tours. Among these, museum tours (33\%) are one of the areas with the largest share. Before and during COVID-19, some museums were using VR in their services. Post COVID-19, it is suggested museums to adapt their assets into
VR. In particular, this will motive travelers to visit the destination and its museums.

- The accommodation sector uses VR to enable travelers to book, manage their reservations, and see what they will experience at the hotel. This is so important that travelers choose specific hotels. Therefore, in a competitive world, the accommodation sector can adopt VR in their service offerings, in doing so, they can differ across other accommodation businesses. Furthermore, this will ease consumers' decision-making process.

- In particular, COVID-19 caused people to not come together in the destination and take care of some sanitations. Restaurants, as a hospitality area which is the most desired to be clean, can present their products via VR by showing 3D images. Moreover, menu designs can be adopted via VR that will reduce human interaction.

Tourist experience quality is in infancyand every improvement on VR will be needed to test the experience quality of tourists. Further studies can examine the role of VR on experience quality, which individuals used this tech during COVID-19. Further to this, researchers can investigate whether VR can enhance destination awareness and promotion as a marketing tool.

\section{References}

A2VR (2020). Virtual Reality in Restaurants. Retrived from https://www.a2vr.co/restaurants in January 6

Ahmad, A., Jamaludin, A., Zuraimi, N. S. M., \& Valeri, M. (2020). Visit intention and destination image in post-Covid-19 crisis recovery. Current Issues in Tourism, 1-6.

Anderson, R. M., Heesterbeek, H., Klinkenberg, D., \& Hollingsworth, T. D. (2020). How will countrybased mitigation measures influence the course of the COVID-19 epidemic? The Lancet, 395(10228), 931-934.

Assaf, A., \& Scuderi, R. (2020). COVID-19 and the recovery of the tourism industry. Tourism Economics.

1-3. https://doi.org/10.1177/1354816620933712

Aydın, B., \& Doğan, M. (2020). Yeni Koronavirüs (COVID-19) Pandemisinin Turistik Tüketici Davranışları ve Türkiye Turizmi Üzerindeki Etkilerinin Değerlendirilmesi. Pazarlama Teorisi ve Uygulamaları Dergisi, 6(1), 93-115.

Beirman, D. (2003). Restoring tourism in crisis: A strategic marketing approach. CABI Publishing.

Bishara, H. (2020, January 6). 2,500 Museums You Can Now Visit Virtually. 
https://hyperallergic.com/547919/2500-virtualmuseum-tours-google-arts-culture/

British Museum. (2020, January 7). The Museum of the World. https://britishmuseum.withgoogle.com/

Buhalis, D., \& Matloka, J. (2013). Technology-enabled tourism destination management and marketing. In Costa, C., Panyk, E. and Buhalis, D. (Eds), Trends in European Tourism Planning and Organisation, Canada: Channel View Publications.

Cheong, R. (1995). The virtual threat to travel and tourism. Tourism management, 16(6), 417-422.

Cranmer, E. E., tom Dieck, M. C., \& Fountoulaki, P. (2020). Exploring the value of augmented reality for tourism. Tourism Management Perspectives, 35, 100672.

Debata, B., Patnaik, P., \& Mishra, A. (2020). COVID-19 pandemic! It's impact on people, economy, and environment. Journal of Public Affairs, e2372.

Govers, R. , Go, F. M. , \& Kumar, K. (2007). Promoting tourism destination image. Journal of Travel Research , 46 (1), 15-23.

Go Turkey. (2020, January 7). Virtual Museum in Turkey. https://www.goturkey.com/blog/virtualmuseum-in-turkey

Gössling, S., Scott, D., \& Hall, C. M. (2020). Pandemics, tourism and global change: a rapid assessment of COVID-19. Journal of Sustainable Tourism, 1-20. https://doi.org/10.1080/09669582.2020.1758708

Guha, A. (2020). Is virtual reality (VR) the future of travel post COVID-19? Retrieved from https://travelandynews.com/is-virtual-reality-vrthe-future-of-travel/

Gustafson, P. (2012). Managing business travel: Developments and dilemmas in corporate travel management. Tourism management, 33(2), 276284.

Guttentag, D. A. (2010). Virtual reality: Applications and implications for tourism. Tourism Management, 31(5), 637-651.

Holonext. (2020, January 7). Göbekli Tepe AR. https://holonext.com/portfolio/gobekli-tepe-ar/

Huddart, D., \& Stott, T. (2020). Adventure Tourism Environmental Impacts and Management. Palgrave Macmillan.

Javaid, M., Haleem, A., Vaishya, R., Bahl, S., Suman, R., \& Vaish, A. (2020). Industry 4.0 technologies and their applications in fighting COVID-19 pandemic. Diabetes and Metabolic Syndrome: Clinical Research and Reviews, 14(4), 419-422.

Karadimitriou, C. (2020). From real to virtual: nature tourism insights. International Journal of Spa $\begin{array}{lcr}\text { and } & \text { Wellness, } & 1-13 . \\ \text { https://doi.org/10.1080/24721735.2020.1770982 }\end{array}$

Kim, M. J., \& Hall, C. M. (2019). A hedonic motivation model in virtual reality tourism: Comparing visitors and non-visitors. International Journal of Information Management, 46, 236-249.

Kim, R. Y. (2020). The Impact of COVID-19 on Consumers: Preparing for Digital Sales. IEEE Engineering Management Review. https://doi.org/10.1109/EMR.2020.2990115

Kock, F., Nørfelt, A., Josiassen, A., Assaf, A. G., \& Tsionas, M. G. (2020). Understanding the COVID19 tourist psyche: The Evolutionary Tourism Paradigm. Annals of tourism research, 85, 103053.

Kutsenko, A. (2019). 7 Ways to Use AR/VR to Improve Guest Engagement. Retrived from https://hospitalitytech.com/7-ways-use-arvrimprove-guest-engagement in january 7 .

Kwok, A. O., \& Koh, S. G. (2020). COVID-19 and extended reality (XR). Current Issues in Tourism, 1-6.

Little Black Book. (2020). Why Virtual Reality May Be the Saviour of the Travel and Tourism Industry. Retrieved from https://www.lbbonline.com/news/why-virtualreality-may-be-the-saviour-of-the-travel-andtourism-industry

Loureiro, S. M. C., Guerreiro, J., \& Ali, F. (2020). 20 years of research on virtual reality and augmented reality in tourism context: A textmining approach. Tourism Management 77, 104028).

Matiza, T. (2020). Post-COVID-19 crisis travel behaviour: towards mitigating the effects of perceived risk. Journal of Tourism Futures. ahead-of-print No. ahead-of-print. https://doi.org/10.1108/JTF-04-2020-0063

Menegaki, A. N. (2020). Hedging Feasibility Perspectives against the COVID-19 for the International Tourism Sector. Preprints 2020, 2020040536 (doi: 10.20944/preprints202004.0536.v1).

Mohanty, P., Hassan, A., \& Ekis, E. (2020). Augmented reality for relaunching tourism post-COVID-19: socially distant, virtually connected. Worldwide Hospitality and Tourism Themes. ahead-of-print. https://doi.org/10.1108/WHATT-07-2020-0073

Mora, C. (2020)."Technological opportunities for the travel and tourism sector emerging from the 2020global health crisis", in Figueira, L. and Oosterbeek, L. (Eds),Turismo Mundial, Crise Sanitaria eFuturo: Instituto Politécnico de Tomar, pp. 33-43.

Morosan, C., \& Bowen, J. T. (2018). Analytic perspectives on online purchasing in hotels: a review of 
literature and research directions. International Journal of Contemporary Hospitality Management, 30(1), 557-580.

Nicola, M., Alsafi, Z., Sohrabi, C., Kerwan, A., Al-Jabir, A., Iosifidis, C., Agha, M., \& Agha, R. (2020). The socio-economic implications of the coronavirus pandemic (COVID-19): A review. International Journal of Surgery, 78, 185-193.

Neuburger, L., \& Egger, R. (2020). Travel risk perception and travel behaviour during the COVID-19 pandemic 2020: A case study of the DACH region. Current Issues in Tourism, 1-14.

OECD. (2020). Tourism Trends and Policies 2020-Policy highlights. Retrieved from https://www.oecd.org/cfe/tourism/oecd-tourismtrends-and-policies-20767773.htm

Özbay, G. (2020). Yiyecek İçecek Sektöründe Postmodern Pazarlama Yaklaşımı Olarak Üstgerçeklik Uygulamalarına İlişkin Bir Değerlendirme. Journal of Tourism Intelligence and Smartness, 3(1), 53-71.

Pearlman, D. M., \& Gates, N. A. (2010). Hosting business meetings and special events in virtual worlds: a fad or the future?. Journal of Convention \& Event Tourism. 11 (4), 247-265.

Pennington-Gray, L. , Schroeder, A. , \& Kaplanidou, K. K. (2011). Examining the influence of past travel experience, general web searching behaviour and risk perception on future travel intentions. International Journal of Safety and Security in Tourism , 1 (1), 64-92.

Phocuswire. (2020). "Can virtual reality help tourism destinations recover from COVID-19?" Available at: https://www.phocuswire.com/can-virtualreality-help-tourism-destinations-recover-covid19 (Accessed on 7 December 2020).

Polyzos, S., Samitas, A., \& Spyridou, A. E. (2020). Tourism demand and the COVID-19 pandemic: an LSTM approach. Tourism Recreation Research, $1-13$. https://doi.org/10.1080/02508281.2020.1777053

Seyitoğlu, F., \& Ivanov, S. (2020). Service robots as a tool for physical distancing in tourism. Current ISsues in Tourism, 1-4. https://doi.org/10.1080/13683500.2020.1774518

Singh, R. P., Javaid, M., Kataria, R., Tyagi, M., Haleem, A., \& Suman, R. (2020). Significant applications of virtual reality for COVID-19 pandemic. Diabetes and Metabolic Syndrome: Clinical Research and Reviews, 14(4), 661-664.

Skinner, T. (2020). Travel - Virtual worlds: Can we travel without travelling? Retrieved from http://www.bbc.com/travel/story/20200330-covid19-virtual-travel-during-coronavirus
Smith, P. W., Hansen, K., Spanbauer, L., \& Shell, D. F. (2007). Pandemic influenza preparedness: A survey of businesses. American Journal of Infection Control, 35(7), 484-485.

Statistica. (2020). Forecast augmented (AR) and virtual reality (VR) market size worldwide from 2016 to $2020 . \quad$ Retrieved from https://www.statista.com/statistics/591181/global -augmented-virtual-reality-market-size/

Ting, H., Ling, J., \& Cheah, J. H. (2020). It Will Go Away!? Pandemic Crisis and Business in Asia. Asian Journal of Business Research, 10(1), 1-7.

Tourismart. (2017). The Power of Beacon Technology in Hotels. Retrived from https://tourismart.co/blog/power-of-beaconstechnology-in-

hotels\#: : text=Beacon\%20is\%20tiny\%2C\%20desi gned $\% 2 \mathrm{C} \% 20$ location, your $\% 20$ hotel $\% 2 \mathrm{C} \% 20$ via $\%$ 20push\%20notification in January 8.

Travel Daily News. (2020). Virtual reality may become a key component in the booking process, says GlobalData | TravelDailyNews International. Retrieved from https://www.traveldailynews.com/post/virtualreality-may-become-a-key-component-in-thebooking-process-says-globaldata

Tussyadiah, I. P., Wang, D., Jung, T. H., \& tom Dieck, M. C. (2018). Virtual reality, presence, and attitude change: Empirical evidence from tourism. Tourism Management, 66, 140-154.

Tussyadiah, I. P., Wang, D., \& Jia, C. H. (2017). Virtual reality and attitudes toward tourism destinations. In R. Schegg, \& B. Stangl. Information and communication technologies in tourism 2017 (pp. 229-239). Springer, Cham.

Uğur, N. G., \& Akbiyık, A. (2020). Impacts of COVID-19 on global tourism industry: A cross-regional comparison. Tourism Management Perspectives, 36, 100744 .

UNESCO. (2020). Virtual Museums on Underwater Cultural Heritage respond to the Covid-19 crisis. Retrieved from https://en.unesco.org/news/virtual-museumsunderwater-cultural-heritage-respond-covid-19crisis

Vaishar, A., \& Štastná, M. (2020). Impact of the COVID19 pandemic on rural tourism in Czechia Preliminary considerations. Current Issues in Tourism, 1-5.

Wall, G., \& Mathieson, A. (2006). Tourism: Change, Impacts and Opportunities. Prentice Hall.

Wen, J., Wang, W., Kozak, M., Liu, X., \& Hou, H. (2020). Many brains are better than one: the importance of interdisciplinary studies on COVID-19 in and 
beyond tourism. Tourism Recreation Research, 15. https://doi.org/10.1080/02508281.2020.1761120

Witte, K., \& Allen, M. (2000). A meta-analysis of fear appeals: Implications for effective public health campaigns. Health education \& behavior, 27(5), 591-615.

World Economic Forum. (2017). Digital Transformation Initiative Aviation, Travel and Tourism Industry. Retrieved http://reports.weforum.org/digitaltransformation/wpcontent/blogs.dir/94/mp/files/pages/files/wef- ${ }^{-d t i}{ }^{-}$ aviation-travel-and-tourism-white-paper.pdf

World Health Organization. (2020). Novel Coronavirus (2019-nCoV) Situation Report - 1. Retrieved from https://apps.who.int/iris/handle/10665/330760

World Tourism Organisation. (2020a). Impact assessment of the COVID-19 outbreak on international tourism. Retrieved from https://www.unwto.org/impact-assessment-ofthe-covid-19-outbreak-on-international-tourism

World Tourism Organization. (2020b). Global Guidelines to Restart Tourism. Retrieved from https://webunwto.s3.eu-west-

1.amazonaws.com/s3fs-public/2020-05/UNWTO-

Global-Guidelines-to-Restart-Tourism.pdf
World Tourism Organization (2020c). "Tourism and Covid-19 - Unprecedented Economic Impacts" available at: https://www.unwto.org/tourism-andcovid-19-unprecedented-economic-impacts (Accessed on 6 December 2020).

Worldometers (2020). "Covid-19 Coronavirus Pandemic" available https://www.worldometers.info/coronavirus/ (Accessed on 6 December 2020).

Yung, R., Khoo-Lattimore, C., Prayag, G., \& Surovaya, E. (2020). Around the world in less than a day: virtual reality, destination image and perceived destination choice risk in family tourism. Tourism Recreation Research, 1-16.

Zeng, Z., Chen, P.-J., \& Lew, A. A. (2020). From hightouch to high-tech: COVID-19 drives robotics adoption. Tourism Geographies, 1-11. https://doi.org/10.1080/14616688.2020.1762118

Zenker, S., \& Kock, F. (2020). The coronavirus pandemic-A critical discussion of a tourism research agenda. Tourism Management, 81, 104164. 


\title{
INFO PAGE
}

\section{Virtual reality technology and physical distancing: A review on limiting human interaction in tourism \\ Abstract}

\begin{abstract}
While the COVID-19 pandemic has been influencing almost all industries since the end of the first quarter of 2020, its impact appears to be more prominent in the tourism industry. Extant research emphasizes that this effect will continue and individuals abstain from travel to avoid being among other people. To maintain physical distancing and recover the tourism industry, virtual reality technology has been adopted to give travelers the opportunity to visit certain destinations and try products or services, which can be a useful tool to consider physical distancing in tourism. Further to this, this research reviews that tourist destinations and tourism businesses such as accommodation, food and beverage, and museums can utilize virtual reality technology to prevent the spread of COVID-19. Furthermore, COVID-19 can be seen as a chance for both the industry and the destination to market their products and services. Therefore, this technology will be extremely helpful for the revival of tourism post-COVID-19.
\end{abstract}

Keywords: Pandemics, COVID-19, Virtual reality technology

\section{Authors}

Full Name Author contribution roles

Ozan Atsız: Conceptualization, Investigation, Resource, Writing-Review \& Editing

Author statement: Author(s) declare(s) that All procedures performed in studies involving human participants were in accordance with the ethical standards of the institutional and/or national research committee and with the 1964 Helsinki declaration and its later amendments or comparable ethical standards.

Ethical statement: The research does not require an ethics committee report. Justification: The methodology of this study does not require an ethics committee report. 